\title{
Development of E-Government Trustworthiness to Increase Public Trust
}

\author{
SUTRISNO $^{1}$, Darius ANTONI ${ }^{2 *}$, and Muhammad AKBAR ${ }^{3}$
}

\author{
${ }^{1}$ Sutrisno.maret@gmail.com, Faculty of Computer Science, Universitas Bina Darma, Palembang, Indonesia \\ ${ }^{2}$ Darius.antoni@binadarma.ac.id, Faculty of Computer Science, Universitas Bina Darma, Palembang, Indonesia \\ ${ }^{3}$ Muhammad.akbar@binadarma.ac.id, Faculty of Computer Science, Universitas Bina Darma, Palembang, Indonesia \\ *Corresponding author: Darius.antoni@binadarma.ac.id
}

\begin{abstract}
The development of Electronic Government (e-government) has become a research topic of interest for researchers worldwide. Various government agencies in Indonesia, mostly, have adopted e-government technology in government management. But the tendency of declining public trust in government becomes a challenge for the government to increase public trust in the government. This research aimed to develop the trustworthiness of e-government to increase public trust in the government. The e-government in this study was developed based on trustworthiness which has three factors: security, transparency and accountability. This study used interview with the Head of Department of Communication and Informatics (DISKOMINFO) of Muara Enim Regency, the Head of Department of Environment and Hygiene (DLHK) of Muara Enim Regency, two staff each from DISKOMINFO and DLHK Muara Enim and the Community to get preliminary information about various issues or problems in Muara Enim Regency. The development of this e-government was using a prototype model to simplify the system design. The result from this study was an e-government prototype refers to the three indicators of trustworthiness which aim to assist the public in reporting (making a report (to the government)).
\end{abstract}

Keywords: public trust, trustworthiness, e-government, security, transparency, accountability, prototype

\section{Preliminary}

The current development is always followed by developments in technology, every technological development should be followed to not outdated. Technology enables data delivery and management facilities have done online. Innovation in today's technology has proven to give a substantial contribution in various areas, including in the governance field. The development of information and communication technologies make complex things simpler, including the public service sector. This online system is expected to improve the relationship between the government and other parties. The sophistication of this technology can be utilized in the implementation of e-government.

E-government is a system or component of government information and communication technology to exchange information to improve governance [1]. E-government technology eases the government to manage the needs of delivering information from the government to the public, business partners, employees, business entities, and other institutions online. This, of course, can make public service better and easier, in various forms of service that they want.

Various government agencies in Indonesia, mostly, have adopted e-government technology in government management. The implementation of e-government in developed countries have shown remarkable success, public service has brought great satisfaction to the public. Successful implementation of e-government in the developed countries has inspired the developing countries to follow the steps in the implementation of e-government.
Muara Enim Government also do not miss (the chance) to adopt e-government in the governance and public service. All regional organizations, ranging from the regional secretariats regent's office, departments, agencies, offices, and other technical institutions have implemented egovernment in the management of the organization.

Some experts warn the tendency of declining public trust in the government [3]. It is a challenge for the government to increase its legitimacy, national competitiveness, and public compliance with government policies, so there is a clear need for the importance of the public trust issue [4].

Public trust is one approach to the development of trust between the citizens and the government to examine the public score of e-government [2][5]. To control the information given, the experience in using e-government with high credibility is needed/required. Credibility is related to the quality of information that can be trusted. The key to credibility identified by many researchers is trustworthiness and expertise. Trustworthiness is described as a well-intentioned, truthful, impartial, and so on. Expertise is a combination of experience, intelligence, skills, and knowledge. Both of these factorstrustworthiness and expertise-generate credibility. Therefore, public trust can be increased when the government increases the development of trustworthiness in the public.

This study focused on developing a system using a prototyping method according to the indicators of trustworthiness to build trust between the public and the government. 


\section{LITERATURE REVIEW}

\section{E-Government}

E-governments a system or component of government information and communication technology to exchange information to improve governance [1]. The benefits that can be felt with the implementation of e-government [2] include:

1. To improve the quality of service from the government to other stakeholders, especially in matters of performance effectiveness and efficiency in various fields of country life.

2. To increase the transparency of the control and accountability of the government administration in an order to implement the concept of Good Corporate Governance.

3. To reduce the total of administrative costs, and their relation and interaction which was issued by the government for everyday activities significantly.

\section{E-Government in Muara Enim Regency}

Based on the IT strategic plan, Muara Enim in ICT implementation is included in the initial stage (Innocence). This stage is marked by the emergence of an awareness of the importance of the information systems implementation, although (it has) not yet covered all of the components of government. As a result, the process of adoption and implementation of information and communication technologies in the governance is still very limited and generally not an integrated initiation. Another characteristic is the absence of adequate knowledge among the existing human resources on standards and best practices in the implementation of e-government. In the prepared ICT Masterplan, (it has been) identified some existing applications and duties analysis of the respective departments/offices, to see whether the development of new applications is needed or not-meaning that they can simply use the existing applications. Based on the identification of the existing conditions it could be concluded as follows (a) the number of applications owned by the Regional Government of Muara Enim is still limited, so it is required to add other applications eventually, (b) the existing applications such as SIAK, e-KTP, etc., are applications from the Central Government/Department, (c) currently there are several agencies that have had applications developed by third parties. The development is based on the needs of each department/offices and generally still operate on their own so that integration between the systems remains a constraint, (c) in relation to the maintenance of existing applications, the person in charge of the maintenance is either from each departments/offices or from outsiders with an almost balanced composition, (d) the frequency of the application use is $65 \%$ used every day, $4 \%$ used once a week, $7 \%$ used oncemonth and the remaining $24 \%$ used based on the needs, (e) the existing application, 94\% are already operating well, $4 \%$ is still under development, and the remaining $2 \%$ is not operating or idle, (f) in relation to the data owned, electronic data storage, mostly, still use a paid product (propitary) such as MS. Excel, MS SQL Server, Oracle, Access, MySQL and SQL Postgre, (g) data backup process, most of the departments/offices (64\%) do backups that are not scheduled but according to the needs, $32 \%$ do backups once a week, $2 \%$ once a month, and the remaining $2 \%$ do backups four times in a year.

Based on the explanation above, it can be seen that the applications and information systems in e-government are still very small/limited and need development aimed at improving the image of the government that is transparent and trusted by the public in order to implement the good governance concept by empowering the people and other parties as government partners in the administration of public policy-making process equitable and transparent.

\section{The Concept of E-Government Trustworthiness}

The development of trust between the public and the government is the primary dimension to examine the public score of e-government[5]. Some experts who have conducted a study about the trustworthiness of egovernment (Carter[9], Belanger[10], Alzahrani[11], Kurfali[12])[6] reminded about the trust owned by the citizens who raises the initiative in the use of e-government influenced by the components of trust in the internet. The government's efforts to foster public trust some of which are making e-government services that provide security and transparency scores for the public so that e-government can be applied in the government.

Information security and privacy of the citizens in egovernment refers to the extent to which governments manage citizens' private information securely. This is often reflected by the individual organization's readiness to safeguard personal information of the citizens and the development of effective laws and regulations on the use of e-government. E-government transparency refers to the extent to which the organization revealed the work/occupation, decision processes and procedures.

Transparency of information is one of the supporting requirements for a government to be viewed as accountable. The linkage between accountability and transparency is when the government can account for all phases and results in the form of information that can be accessed easily, openly and transparently, so that there would be no "covered" impression.

Based on the explanation above, the indicators of trustworthiness can be shown in Table 1 below: 
Table 1. Indicators Trustworthiness

\begin{tabular}{|c|l|l|l|}
\hline No & Indicator & Implementation & Purpose \\
\hline 1. & Security & Data security & $\begin{array}{l}\text { Protection of data } \\
\text { from the } \\
\text { unauthorized } \\
\text { authorization }\end{array}$ \\
\hline 2. & Transparency & $\begin{array}{l}\text { Information } \\
\text { Transparency }\end{array}$ & $\begin{array}{l}\text { Disclosure of } \\
\text { information }\end{array}$ \\
\hline 3. & Accountability & $\begin{array}{l}\text { Accountability } \\
\text { Systems }\end{array}$ & $\begin{array}{l}\text { Accountability of } \\
\text { accountability } \\
\text { report that has been } \\
\text { developed } \\
\text { previously }\end{array}$ \\
\hline
\end{tabular}

\section{RESEARCH}

\section{Methodology Interview}

Interview is one of the technique in data collection, where it is used by the researcher(s) if they want to conduct a preliminary study to find the issues that should be investigated[7]. The researchers interviewed 10 people consisting of Head of Department of Communication and Informatics (KOMINFO) Muara Enim, two staff of each of the Department of Communication and Informatics and Local Development Planning Agency (Bappeda) Muara Enim and the public (people of Muara Enim) to obtain preliminary information on issues or problems in Muara Enim.

\section{Design}

The steps taken in designing the e-government system based on the public and government functions as the clean controller of Muara Enim Regency by using the prototype method. There are five early stages of the prototype[8], as follows:

1. Communication

The researchers communicate with the people in the sub-district of Muara Enim. From communication, the researchers get results to increase public trust by using indicators of trustworthiness.

2. Quick Plan

Make a simple overview of the software that would be developed following communications made in the previous stage. This scheme/stage describes the forms of the user interface, use case and activity diagrams which are made as preparation to create a design model prototype.

3. Modeling Design Quick
Creating a simple prototype design as the software to be developed. The design was created using photoshop software to make it more attractive and understandable to the public. The prototype that has been created would then be submitted to the public and then they would perform specific evaluations of the prototype that was created/made.

Feedback from the public was used to refine the specification of requirements. At the same time, (this would) allow the researchers to better understand the needs of the public.

4. Construction of Prototype

The system that would be built according to the prototype has met the needs of the public. The system would be built in the form of a mobile application android operating system.

5. Deployment, Delivery and Feedback System The system that has been made/created was submitted to the public and they (the public) were asked for feedback. Feedback from the public is the answer to the question that formed by the researchers by using the indicators of trustworthiness.

\section{RESULTS AND DISCUSSION}

Based on the results of the interviews conducted, the process of implementing the three indicators of trustworthiness is as follows:

\section{IMPLEMENTATION DATA SECURITY IN E-GOVERNMENT}

Data security is the protection of data from unauthorized authorization, modification, or destruction, and the protection of computer systems against unauthorized use. Based on the questions asked by the researchers to DISKOMINFO and DLHK of Muara Enim Regency, (they) said that: 
"Confidentiality of data and information from the public must be secured by the best cryptographic technique so that the data is safe from third parties. Then authentication is added before reporting activities."

Rijndael algorithm is an algorithm that is quite difficult to solve at this time because there are no attacks or solutions that have not been able to mathematically analyze effectively and efficiently with the reason that the pattern formed is quite random. Rijndael has the advantage of having memory power and computational speed in operation. Operations that do not take up too much memory are much in demand by the market because of the need for relatively fast time efficiency [13]. Therefore, the storage of personal data and reports from the public are encrypted using the Cryptographic Rijndael algorithm to be more secure, efficient and difficult to solve.

Implementation of data security for the e-government system developed is as follows:

1. The process of the public accounts registration

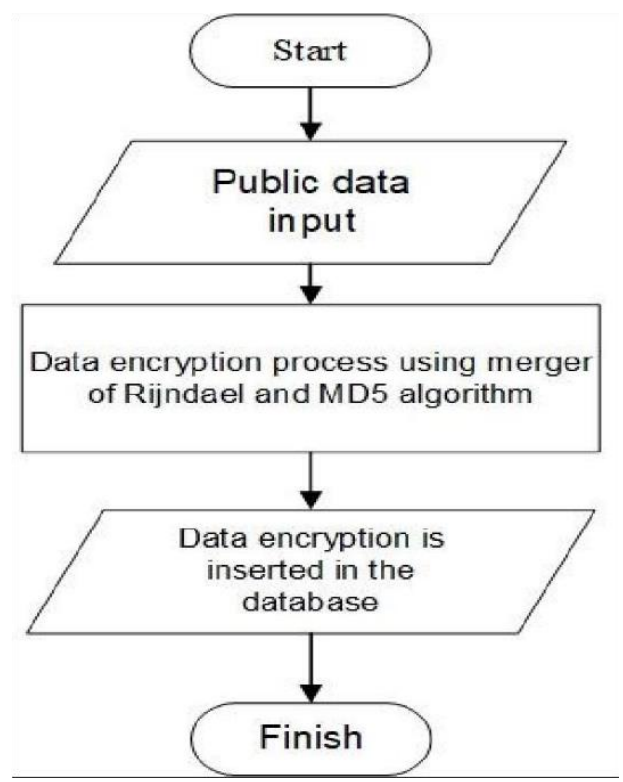

Figure 1. Flowchart Data Account Storage

The process is started with data registering/filling on the form provided. Then the system processes the data into encrypted data using Rijndael cryptography. Furthermore, the data is encrypted again using MD5 cryptography. After the encryption process is complete, the data encryption is put into a database and the storage process is completed. The process flow can be seen in figure 1 .

The flowchart above illustrates the flow of public data storage encrypted using the Rijndael algorithm. Besides being safe, the process of operating data does not consume too muchmemory and is relatively fast[13].

\section{Public reporting process}

The process is started by capturing pictures and filling information to be reported. Then the system retrieves the data location based on the corresponding GPS and processes the data into data encrypted using Rijndael cryptography than the data is encrypted again using MD5 cryptography. After the encryption process is complete, the data encryption is put into a database and reporting process is completed. The process flow can be seen in Figure 2.

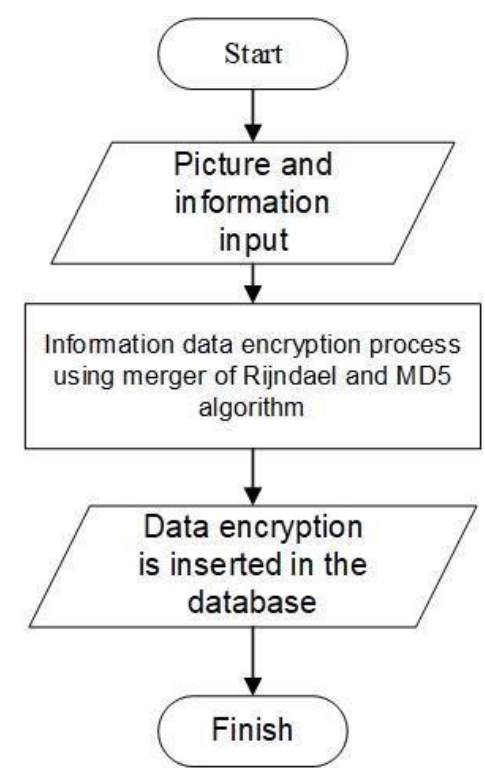

Figure 2. Flowchart Sending Report

The flowchart above illustrates the flow of report data storage provided by the public which is encrypted using the Rijndael algorithm. Besides being safe, the process of operating data does not consume too much memory and is relatively fast[13].

\section{IMPLEMENTATION OF TRANSPARENCY INFORMATION IN E- GOVERNMENT}

Transparency is all decisions taken and their application is made and implemented following applicable legal and regulatory corridors. This also includes the understanding that information is freely available and can be accessed easily and directly[14]. Based on the questions asked by the researchers to people of Muara Enim Regency, (they) said that:

"Information displayed should be transparent, grading the rating from the public to the public. Also, (there should be) written assessment in the system settings based on the estimated time to deal with the reported location"

Other people also said that:

"Estimated processing time displayed on the reports from the public. For the responsiveness to public reports, administrators must respond to the report based on the reported location."

Implementation of information transparency for egovernment systems developed for the application of report responses, estimated response time, rating of the system and rating from the community directly, that is:

1. The process of a feedback report

The process is started from the admin choosing the report that would be addressed. Then the system will obtain data location from the public statements and GPS data location of the admin, then both locations are compared, if the admin location is currently on the reported location then system will open the camera, otherwise if admin is not on the reported location, then a notification that you are not on the location will appear. The process flow can be seen in figure 3. 


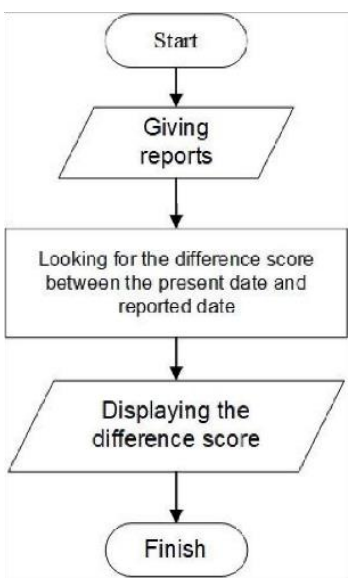

Figure 3. Flowchart of Reports Feedback Process

The flowchart above illustrates the flow of the admin transparency process in responding to reports from the community that must be responded to at the reported location, so that information is received directly from the location[14].

2. The estimation time process for responsiveness on the report given by the public

The process is started from the public reporting. Then the system looks for the difference score between the present date and the date of the public report. Further, showing the estimated time for the responsiveness of the public report. Here is a flowchart of the process and display of the estimated time for responsiveness to the public reports. The display can be seen in Figure 4 and process flow can be seen in figure 5 .

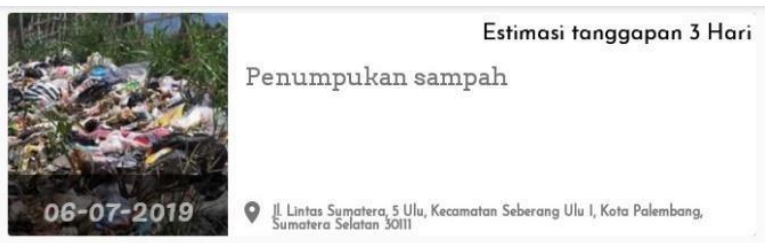

Figure 4. Display of Estimated Response Time

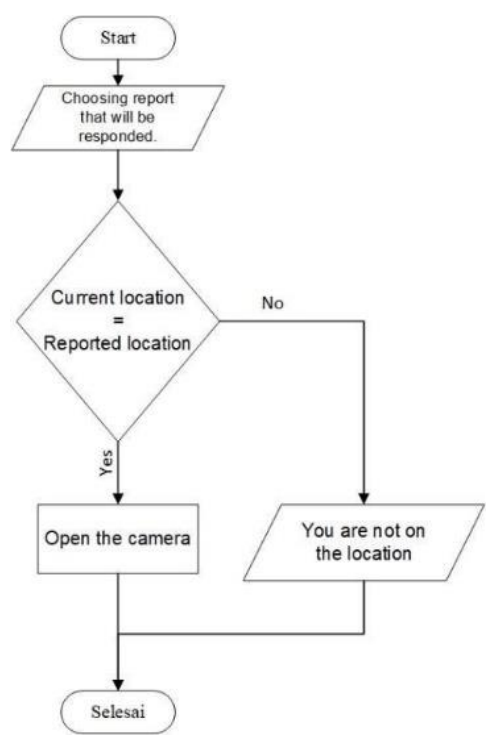

Figure 5. Flowchart of Estimated Response Time.
The flowchart above illustrates the flow of the process of transparency of the estimated response time of community reports according to the reported location so that the information received is following the response time of the $\operatorname{admin}[14]$.

3. The process of rating accumulation area by the public

The process is started by giving the rating by the public. Then the score is accumulated with other public ratings and divided to the number (of people) that give ratings based on the reported location. Furthermore, the result is displayed on the main menu of the application. Here are a flowchart and display of the rating accumulation process per are by the public. The display can be seen in Figure 6 and process flow can be seen in Figure 7.

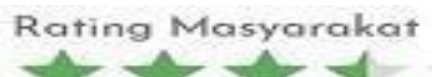

Figure 6. Display of Rating by the Public

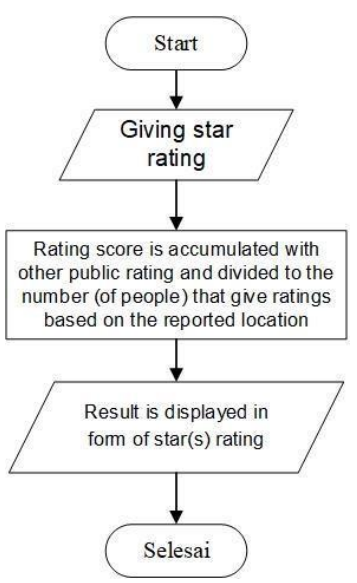

Figure 7. Flowchart of Public Rating

The flowchart above illustrates the flow of the transparency rating process from the community according to the reported location so that the information received is following the community's evaluation[14].

4. The process rating accumulation area from the system

The process is started from the public reporting. Then the system looks for the score of the difference between the present date and the date of the public report. The difference is compared with the score that has been applied in the program, if the score of the difference is smallerequal to 12 and greater equal to 10 then the rating score is 5 , or if the score of the difference is smaller equal to 9 and greater equal to 7 , the rating score is 4 , or if the score of the difference is smaller equal to 6 and greater equal to 4 then the rating score is 3 , or if the score of the difference is smaller equal to 3 and greater equal to 1 then the rating score is 2 , or if the score of the difference is smaller equal to 0 then the rating score is 1 . Furthermore, the rating score is accumulated with other rating systems divided by the number of all ratings based on the reported location. Furthermore, the result is displayed on the main menu of the application. Here is a flowchart and display of the rating accumulation process per area from the system. The display can be seen in Figure 8 and process flow can be seen in Figure 9. 


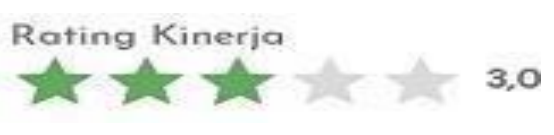

Figure 8. Display of Rating from Systems

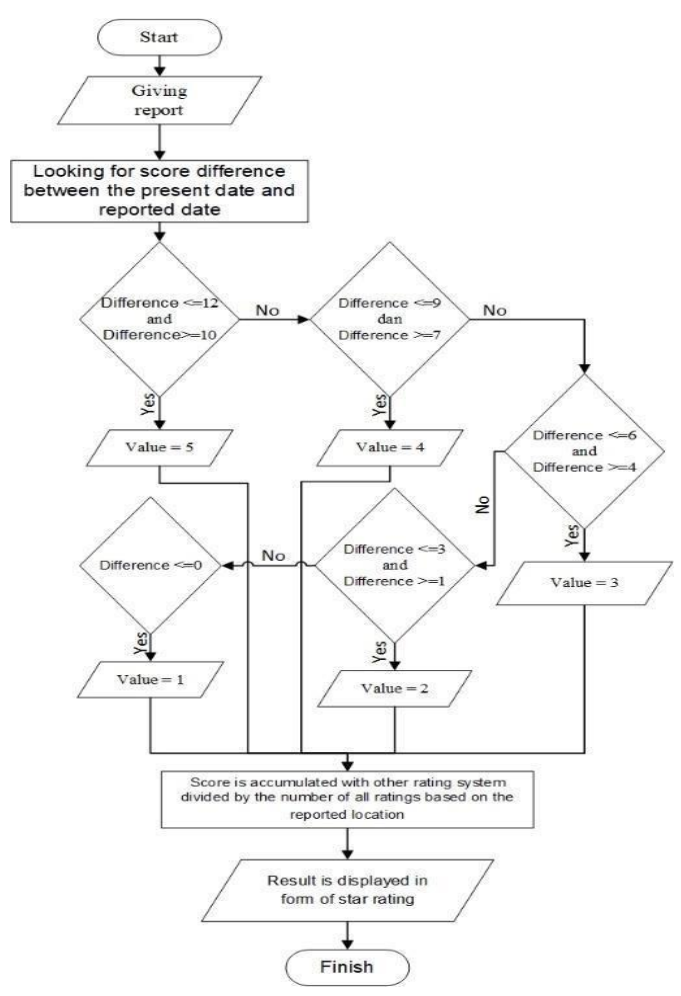

Figure 9. Rating Flowchart of System

The flowchart above illustrates the flow of the transparency rating process of the system according to the reported location so that the information received is following the programmed system evaluation according to the admin's response time[14].

\section{IMPLEMENTATION OF ACCOUNTABILITY IN E-GOVERNMENT}

Accountability is a measure that indicates whether public bureaucratic activities or services carried out by the government are following the norms and values adopted by the people and whether the public service can accommodate the actual needs of the people[15].

Following is the implementation of accountability for the developed e-government system as follows:

1. Personal data and reports given by the public are kept confidential.

2. Admin responsiveness that is reviewed directly on the location, because the responsiveness of the public report can only be done on the reported location.

3. The availability of estimated response time.

4. The rating score from the public (is) directly accumulated and displayed based on the reported location.

5. The rating score from the system is following preprogrammed calculations provided based on the admin working time, then accumulated and displayed based on the reported location.

\section{CONCLUSION}

This research presents the development of e-government services to increase public trust in government. This system was developed by reviewing previous research gathered at Muara Enim, Indonesia. This study concludes that egovernment services in increasing public trust can be improved through three indicators of trustworthiness namely security, transparency and accountability. Also, with this system, the government and the community can be fast and responsive to theenvironment.

\section{REFERENCES}

[1] Antoni, D., Akbar, M., \& Fatoni, F., Electronic Government Rukun Tetangga Model. (2018) 64-73.

[2] Antoni, D., Herdiansyah, M. I., \& Akbar, M. Critical factors of transparency and trust for evaluating e-government services for the poor. Second International Conference on Informatics and Computing (ICIC) (2017)(pp. 1-6). Papua: IEEE.

[3] Walle, S. V., Roosbroek, S. V., \& Bouckaert, G. Trust In The Public Sector: Is There Any Evidence For A Long-Term Decline International Review of Administrative Sciences, (2008) 45-62.

[4] Lee, A.-R. Down and Down We Go Trust and Compliance in South Korea. Social Science Quarterly, (2003) 329-343.

[5] Sodhi, I. S. In Trends, Prospects, and Challenges in Asian E-Governance. (2015) (pp. 142-144). St. Wilfred's PG College: IGI Global.

[6] Muflihah, Y., \& Susanto, T. D. Faktor Yang Mempengaruhi Warga Dan Pemerintah Dalam Adopsi E-Government: Sebuah Ulasan Sistematis, (2017) 307309.

[7] Sugiyono. Metode Penelitian Bisnis. Bandung: Alfabeta. (2017).

[8] Pressman, R. S.Software Engineering: A Practitioner'S Approach, Seventh Edition. Avenue Of The Americas New York: McGraw-Hill Education. (2010).

[9] Carter, L. B. The utilization of e-government services: citizen trust, innovation and acceptance factors. Information Systems Journal, (2005) 5-25.

[10] Bélanger, F. C. Trust and risk in e-government adoption. The Journal of Strategic Information Systems, (2008) 165-176.

[11] Alzahrani, L. W. A. K. Analyzing the critical factors influencing trust in e-government adoption from citizens' perspective: A systematic review and a conceptual framework. International Business Review, (2016) 1-12. 
[14] Riant Nugroho Dwijowijoto, Public Policy: Formulation, Implementation, and Evaluation, Jakarta, Elex Media Komputindo, (2003) 128.

services in Turkey. Computers in Human Behavior, (2017) 168-178.

[13] Permana, A. A., \& Nurnaningsih, D. Design of Data Security Application with ADVANCED ENCRYPTION STANDARD (AES) Algorithm. (2018) 177- 186.
[15] Kumorotomo, w. Public Bureaucracy Accountability. Yogyakarta. Offset Student Library. (2005) 3 . 